\title{
SCHILDEREN IN INDIË ${ }^{1}$
}

'Schrijf eens iets over schilderen in Indië'; dit werd mij verzocht door een der meest vooraanstaande kunstbeschermers op Java. Impulsief beloofde ik, aan dit verzoek te zullen voldoen, maar nu ik die belofte wil inlossen, besef ik, dat impulsie ons parten kan spelen.

Primo is het voor een schilder lastig over schilderen te schrijven, zonder de onbescheidenheid te begaan, over eigen werk en zich zelf te vertellen. Secundo is het schrijven over schilderen op zich zelf vaak een onbegonnen werk, omdat de meeste aandoeningen en stemmingen, welke men al schilderend ondervindt, zich niet of zeer vaag laten beschrijven. Ten slotte schrik ik terug voor de veelzijdigheid van het onderwerp. Wie Indië kent, wie hier de vibreerende vlakten, de ruig begroeide bergen, de liefelijke kusten, de wondere zonsondergangen en de rookende vulkanen gezien heeft, zal dit begrijpen.

Indië overdondert den schilder, die hier voet aan wal zet en direct aan het reizen slaat. Het schokt hem in een kort tijdsbestek te hevig. Heel wat tijd is er noodig, om van den eersten schrik te bekomen en voldoende zelfbeheersching te krijgen, om de tropennatuur rustig te bestudeeren, kalm te onderzoeken, wat het eigenlijk in die natuur is, dat hem zoo geweldig schokte. $\mathrm{Na}$ lange studie en veel werken komt men eindelijk tot de verrassende conclusie, dat het meest treffende, het wonderlijkste in de Indische natuur veroorzaakt wordt door uiterst kleine verschillen met de Europeesche tinten en kleurcombinaties. Dit juist maakt m.i. het schilderen in Indië zoo moeilijk.

Wie niet streng sober weet te blijven bij de uitbeelding van de machtige emoties, slaagt hier niet. Indië is wonderbaar schoon, niet omdat het hooge bergen heeft en de zon hier fel brandt, maar omdat het in zijne kleurnuanceringen van die kleine, fijne verschillen met het Westen biedt. Zeer zeker, Indië frappeert door zijn warmen gloed, door zijn felle kleurencontrasten, maar die vindt men in het Westen ook. Het eigen cachet ontleent het Indisch palet aan zijn in het Westen onbestaanbare kleurschakeeringen en overgangen.

Wat compositie en lijn betreft, springen de verschillen met Europa veel gemakkelijker in het oog en levert de Indische natuur niet zoveel moeilijkheden op. Ik heb hier Europeesche schilders zien werken, die heel vlug juiste, hoogstaande composities gaven, maar maandenlang sukkelden met de tinten en de tropische atmospheer. Wie Indië schilderen wil, moet er lang blijven. Indië pakt ons op het eerste gezicht, maar laat zich pas pakken als men er jaren-lang vertoefd heeft. De schilder in Indië heeft met technische moeilijkheden te kampen, die de Hollandsche collega's onbekend zijn De klimaatsinvloeden doen zich gelden op de verven. Verven, welke in Europa bestendigcess 
Afb. 1

Willem Imandt en zijn vrouw Eliza Robijns met hun eerste zoon Wim op 2 september 1910 in Malang (Java).

Foto: Photographie Kwee Djen Cinh.

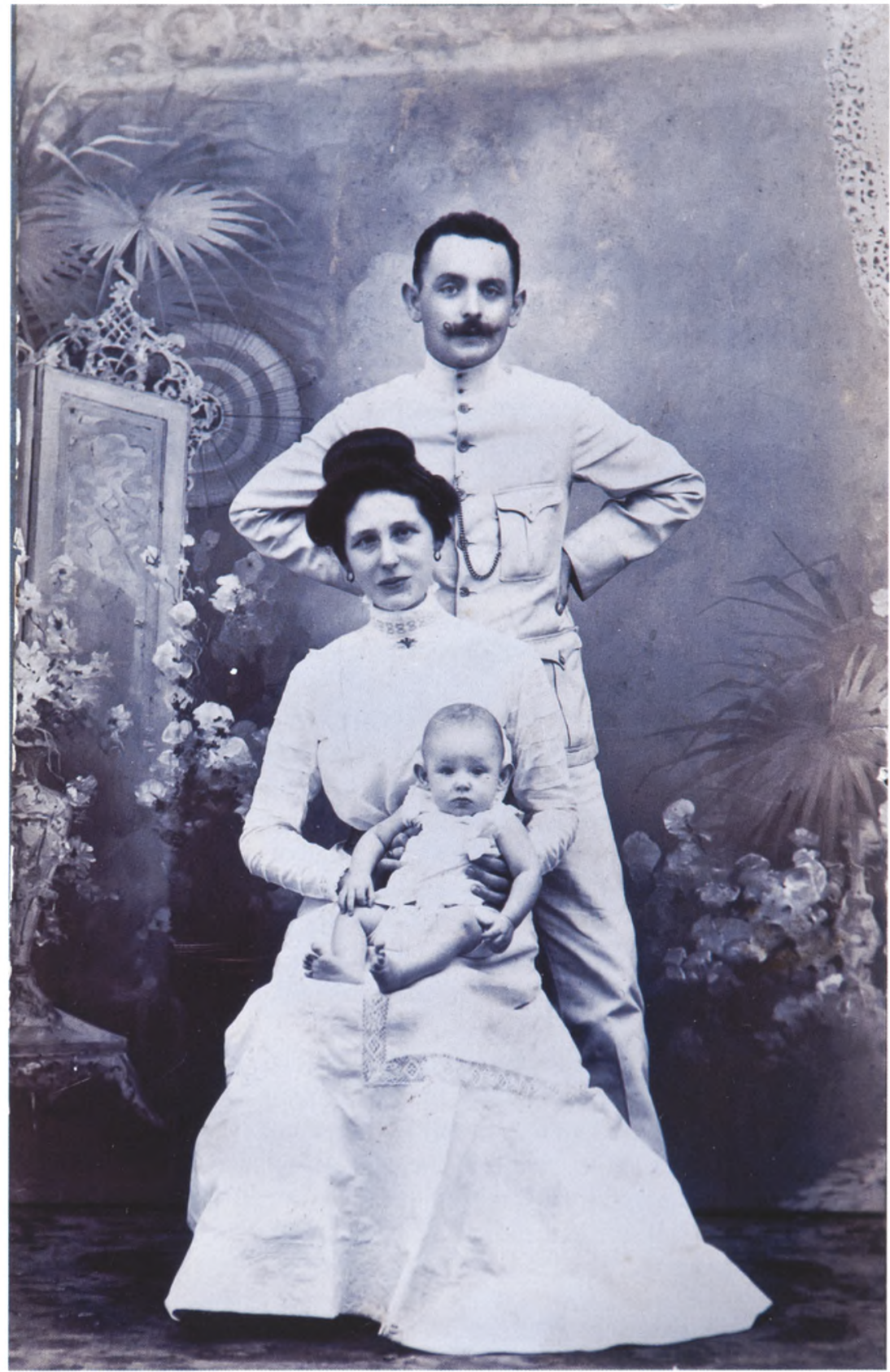


heeten, zijn vaak niet te gebruiken, doordat ze hier veranderen, scheikundige verbindingen aangaan met stoffen, waarmede de tropische lucht vaak bezwangerd is.

Bij het mengen stuit men eveneens op bezwaren en moet men door jarenlange ondervinding eindelijk vinden, welke verven hier niet en welke wel scheikundig op elkaar inwerken, en in welke verhoudingen men ze ongestraft vermengen kan. Ook het nadonkeren heeft hier veel vlugger en veel intenser plaats dan in Europa. Bij het opzetten van een doek dient men reeds te taxeeren, in welke mate de opgezette tinten zullen nadonkeren. In Europa onderscheidt men landschap-, zee-, portretschilders enz. Hier zou men de eerste categorie weer moeten verdeelen in tal van onder-categorieën. Hier vindt b.v. de schilder van boompartijen stof te over om zijn gansche schildersleven te vullen.

$\mathrm{O}$, die boomen, die ongerepte boomen, die vaak het begrip 'boom' weinig meer dekken, maar meer trotsche, grillige monumenten zijn, wier architectuur de Goddelijke meesterhand verraadt. De Indische boomen, vaak van top tot voet bedekt en behangen met mossen en klimplanten, wekken een idee van macht, van grootheid, van een steeds hooger opgaan en zijn bovendien omhuld door een geheimnisvolle sfeer. Wie onderging nooit de mystiek van den waringin? 'Op een Indisch doek moeten klapperboomen en sawah's voorkomen'. Hoe vaak wordt ons dit niet als een zacht verwijt toegevoegd! Ik geef evenwel alle klappers en sawah's voor één Indischen woudreus. Zeker, ik heb onnoemlijk veel klappers en sawah's op het doek gebracht (ook een schilder moet op stuk van zaken leven en geld verdienen), maar nu de moeilijkste jaren voor mij voorbij zijn, schilder ik bij voorkeur oude, ongerepte boomen in hun omgeving, Inlandsche kerkhoven, heilige plekken.

Daar ben ik zoowaar reeds in de onbescheiden fout gevallen, voor welke ik in mijn aanhef vreesde. Ik zie evenwel geen kans, deze onbescheidenheid geheel te vermijden, wijl ik 't nog even moet hebben over den Indischen schilder in zijn verhouding tot pers en publiek. Sprak ik zooeven over moeilijke jaren, dan was ik niet billik.

Werkelijk moeilijk door te worstelen jaren, zooals de meeste collega's in Europa moeten doormaken, kent de Indische schilder niet, als hij pers en publiek van zijn ernstig pogen weet te overtuigen.

Ik heb vijftien jaren lang in Indië geschilderd en nu ik er zachtjes over ga denken, om het oude werelddeel weer op te zoeken, denk ik dankbaar terug aan de hartelijkheid, welke ik vaak ondervond van de Indische pers en het Indisch publiek.

\section{Noot}

1. Oorspronkelijk gepubliceerd in Maandblad voor Beeldende Kunsten 3 (1926), 338-9. 